Educational Research for Social Change (ERSC)

Volume 9 No. 2 September 2020

pp. 101-115

ersc.nmmu.ac.za

ISSN: 2221-4070

\title{
Decolonial Reflections on the Zimbabwean Primary and Secondary School Curriculum Reform Journey ${ }^{1}$
}

\author{
John Bhurekeni \\ Rhodes University Environmental Learning Research Centre, South Africa \\ bhurekenijohn@ymail.com
}

\begin{abstract}
The Zimbabwean curriculum reform journey is shaped by the weight of cultural technologies of domination employed in the country during British imperial rule (1890-1980). Moreover, these imperial forms of domination that, paradoxically, continue to exist today influence the sociocultural and political institutions in the country and delineate what is epistemologically feasible. In addition, the inherited education curricula, specifically at primary school level (the focus of this study) were theoretically and pedagogically disengaged from the lifeworlds of the learners they intended to educate. In this conceptual article, I challenge this colonially inherited education and the paradox of superficial interpretation of unhu/ubuntu (ironically, a doxa in the postcolonial Zimbabwean education system). Further, I suggest considering epistemic depth in pedagogy as an experience that transforms education and society.
\end{abstract}

Keywords: decolonial philosophy, curriculum reform, superficial philosophy, cultural technologies of domination, heritage education, social abjection

Copyright: (C) 2020 Bhurekeni

This is an open access article distributed under the terms of the Creative Commons Attribution NonCommercial License, which permits unrestricted non-commercial use, distribution, and reproduction in any medium, provided the original author and source are credited.

Please reference as: Bhurekeni, J. (2020 Decolonial Reflections on the Zimbabwean Primary and Secondary School Curriculum Reform Journey. Educational Research for Social Change, 9(2), 101-115 http://dx.doi.org/10.17159/2221-4070/2020/v9i2a7

\section{Context and Background}

Zimbabwe is currently in a phase of curriculum reform that, with its emphasis on heritage, promises to contribute to decolonialising an inherited and culturally hegemonic, colonially shaped curriculum (Presidential Commission of Inquiry into Education and Training [CIET], 1999; Zimbabwe Ministry of Primary and Secondary Education [MoPSE], 2014). Shizha and Kariwo (2011) and Mgqwashu (2016) concurred that Zimbabwe, like many African states, coopted imperial educational values that became valued as crucial vehicles of development in postcolonial states. The history of colonised peoples all

\footnotetext{
${ }^{1}$ Ethical clearance number: 2017.12.08.04
} 
over the world, including Zimbabwe, was shaped through cultural technologies of domination ${ }^{2}$ that continue into the present day (Terreblanche, 2014). In the Zimbabwean case, these continuities exist in the form of epistemic and ontological exclusions in curricula despite 40 years of independence from 98 years of British colonial rule.

Much has been written about the colonial history of education in Zimbabwe (Chitumba, 2013; Masaka, 2016; Siyakwazi \& Siyakwazi, 2013) but there is inadequate scholarly analysis of the continuity of imperial cultural hegemony in curriculum and pedagogy. This continuity is paradoxically making its way into the current education reform process with its interest in foregrounding heritage. In reality, British colonial education in Zimbabwe created secular hierarchies incompatible with precolonial, heritage learning pathways (MoPSE, 2014).

This paper offers a critical macrohistorical political sociology of the colonial history of curriculum and how it has influenced pedagogy. Then, the analysis is deepened in the contemporary context of curriculum reform via a critical postcolonial discourse analysis of key policy texts (CIET, 1999 and MoPSE, 2014) that emphasise unhu/ubuntu philosophy as the foundation of the educational reform. The intention of the two-part analysis is to open up a landscape for curriculum and pedagogical development in a way that rigorously engages the potential of the heritage-based commitment of the current educational reform process.

In Part 1 of the analysis (an in-depth literature review to scope the history of curriculum in Zimbabwe as influenced by the cultural hegemonies of colonialism), the curriculum as constituted via the histories of missionary and colonial education is shown to have produced social abjections that caused a decontextual impasse-with curricula and pedagogy being theoretically and practically disconnected from the lifeworlds of African children (CIET, 1999). This differs substantively from precolonial forms of education Rodney (1983), and it is this disjuncture that has motivated a contemporary focus on heritage as the foundation for curriculum reform.

In Part 2 of the analysis, I focus on the ubuntu/unhu discourse where I found a paradox of superficial interpretation of unhu/ubuntu that has, ironically, become a doxa ${ }^{3}$ in the postcolonial Zimbabwe curriculum. This indicates a need for deeper engagement with the unhu/ubuntu philosophy and associated heritage discourse if they are to meet intended aspirations of decoloniality in contemporary times. In practice, this has implications for reframing curriculum in ways that can realise epistemic depth in pedagogy to avoid the limitations of the doxa. This, in turn, has implications for pedagogy, the role of the teacher, and the sociocultural foundations of educational theory and practice. The paper does not offer theory or a methodology of practice but, rather, a critical historical sociological vantage from which to develop this theory and methodology of practice to inform subsequent educational transformation.

\section{Problem Statement and Methodological Approach}

The brutal histories of colonial education and the paradoxical continuity of coloniality mentioned above have influenced an educational reflex that has paved the way for the unhu/ubuntu philosophy to become significant in the Zimbabwean education discourse (CIET, 1999; MoPSE, 2014). However, the continuity of colonial patronage systems and a deficit of diversity in reason make it difficult to take

\footnotetext{
${ }^{2}$ Cultural technologies of domination represent the synthesis of religion, culture, political economic development, ideology, and monolithic epistemic access options into the curriculum in order to suppress the culture, knowledges, religion, and ideologies of the colonised people (see, Terreblanche, 2014).

3 "Doxa" in this article is a commonly believed public opinion that is an unjustifiable ideological doctrine; "episteme" is a more justified belief.
} 
the unhu/ubuntu decolonial narrative into the methodology and learning processes in classroom context. According to Prinsloo (2013), this creates a substantial deficit in methodological examplesmaking it a real challenge to develop a coherent position and line of argument in curriculum transformation. This problem has influenced a number of methodological approaches such as the critical macrohistorical political sociology (Subrt, 2017) and critical postcolonial discourse analysis (Sawyer, 2012).

This paper begins to address this problem via offering, in Part 1, a critical macrohistorical political sociology of the colonial history of curriculum and how it has influenced pedagogy. Critical macrohistorical political sociology as a methodology implies a multi-paradigmatic approach in research with the aim of gathering evidence and communicating ideas about the past (Subrt, 2017). This methodology aims to achieve a number of objectives: mapping metaphysical and epistemological exclusions in colonially inherited education, tracing those cultural hegemonic exclusions to their source, and seeking ways on how heritage education reform intentions could recast new educational existentialities for the Zimbabwean learner. Thus, the methodology denotes the collecting and synthesising of earlier research with the aim of accessing collective evidence in a particular social phenomenon (Tranfield et al., 2003). To this end, critical macrohistorical political sociology has the capacity to shed light for researchers in education on the observable gaps that surface when one engages with critical issues in education such as curriculum transformation and the embedded continuities of coloniality (Sever, 2012). Through this, the intention in this paper was to bring to the fore a historically sensitive and yet generally relatable elucidation of the emergence of cultural technologies of dominance, epistemic and ontological exclusions in curricula (CIET, 1999) and other core features of the Zimbabwean education landscape.

In Part 2, this analysis is deepened in the contemporary context of the curriculum reform via a critical postcolonial discourse analysis of key policy texts that emphasise unhu/ubuntu philosophy as the foundation of the educational reform (CIET, 1999; MoPSE, 2014). According to Fairclough and Wodak (1997), discourse analysis is a theoretical and methodological approach that helps researchers study "how power relations, and ideological standpoints, are exercised and negotiated in discourse" (p. 272). In this paper, critical postcolonial discourse analysis was applied to analyse Zimbabwean educational discourse in sociopolitical contexts, and helped to unveil underlying discursive educational practices such as cultural alienation, creation of social abjection, and continuities of a resilient colonial epistemological mechanism.

I undertake this two-part analysis to give meaning to the point made by Houtondji (1996) and Wiredu (1998), who argued that any philosophy of curriculum transformation must aim to be the main informant to a process where the theoretical framework of the culture is critically examined and enacted. As argued earlier, the postcolonial Zimbabwean education system inherited a culturally devoid colonial education (Shizha \& Kariwo, 2011). Results from the two-part analysis are presented in the next two sections. Of particular attention in the first is how the colonial history of curriculum has influenced pedagogy in contemporary Zimbabwe.

\section{Part 1: Colonial History of Curriculum and how It Influenced Pedagogy}

In Part 1 of this analysis (where I employed an in-depth literature review to scope out the history of curriculum in Zimbabwe as influenced by the cultural hegemonies of colonialism [Terreblanche, 2014]), I found that the curriculum as constituted via the histories of missionary and colonial education produced social abjections ${ }^{4}$ and a decontextual impasse-with curricula and pedagogy being

\footnotetext{
4 "Social abjection" in this article is associated with a process where exclusion is elected as a way of constituting power for the sole benefit of the elite or ruling class.
} 
theoretically and practically disconnected from the lifeworlds of African children (CIET, 1999; MoPSE, 2014). The history of colonised peoples all over the world, including Zimbabweans, was shaped through "cultural technologies of dominance" (Terreblanche, 2014, p. 88) that continue into the present day.

\begin{abstract}
The history of colonised people . . . was shaped through cultural technologies of dominance. Colonial and imperial domination operated through mechanisms education, religion and political economic development [emphasis added] that resulted in cultural imperialism, that is, a debasement and negation of the values of colonial people that undermined their cultures. . . Cultural strategies were more subtle than other forms of colonial control, such as policing and the law, and had some success, in that the colonised internalised inferiority. (Terreblanche, 2014, p. 88)
\end{abstract}

One may surmise that British colonialism in Zimbabwe, and other territories where it was enacted, was educationally and ontologically oriented through Christian missionary doctrines in ways that would deny indigenous people of viable philosophical systems and meaningful and organised learning programmes (Masaka, 2016; Shizha \& Kariwo, 2011). Imperial British colonial education is viewed here as not being meaningful because it was, according to Rodney (1983), not an outgrowth of the values and needs of the people it sought to represent. He argued that "under normal circumstances, education grows out of the environment; the learning process being directly related to the pattern of work in the society" (Rodney, 1983, p. 375). And he cited an example of children from the Bemba community of present day Zambia who "by the age of six could name fifty to sixty species of tree plants without hesitation, but they knew very little about ornamental flowers" (Rodney, 1983, p. 376); these children were able to name the trees because knowledge of trees was a necessity in an agricultural community that often employed slash-and-burn techniques.

In precolonial learning institutions in Africa, Zimbabwe included, education was a process through which continuity was maintained between the elder generation and their children because learning was largely a means of social integration (Kallaway, 1984; Masaka, 2016; Rodney, 1983). Christian missionary institutions and British formal education changed the function of education through their use of cultural technologies of domination that created discontinuities by making school knowledge accessible only to the neophytes (Kallaway, 1984), and by focusing on literary training, technical training, and teaching of crafts and agriculture to provide for the labour needs of the colonial administration, with English as medium of instruction for grades above lower primary (Lugard, 1922). Rudimentary training in elementary hygiene, religious and moral education, and colloquial English constituted part of the African education curriculum in many rural schools (Lugard, 1922). As a result, imperial British education in Zimbabwe failed to effect conceivable notions of cultural development. Wa Thiong'o (1986) and Achebe (2000) concurred that one of the main objectives of colonialism, especially via its Christian missionary institutions of education, was to destroy as much as possible the psycho-cultural being of the Africans (Wa Thiong'o, 1986).

According to Abdi (2012), the discontinuities and annihilation of the psycho-cultural being of Africans that resulted in the production of social abjection and a curriculum decontextual impasse during the colonial period (1890-1980) were to ensure that schools served as a key means of Christian conversion. Hence, the main aim of the colonial education system was to bring "light" and "civility" to "barbaric" communities. To this end, Christian missionaries designed an education system that would foster the belief that the African learner's lifeworld was myopic and superstitious (Wa Thiong'o, 1986). Once this belief was implanted, the colonial school became an abject space responsible for the social uprooting of the African child. Abdi (2009) noted that the process of colonialism saw indigenous ways of learning rooted in the cultural history of practice of oral societies being regarded as stagnated in the past and 
lacking innovative alternatives that would make them attractive and acceptable in the new modalities of colonial relationships. The colonial pedagogy was based on objectives of education that were premised on othering, cultural dislodgment, epistemological domination, and implanting mediocrityrather than stemmed from the interests of the child (Hailey, 1938; Masaka, 2016; Shava, 2008; Shizha \& Kariwo, 2011). Said (1985) and Masaka (2016) argued that power and dominance were the variables used to carve privileges for the colonial masters at the expense of the other citizens.

Rodney (1983) described the colonial schooling system as an "education for subordination, exploitation, the creation of mental confusion and the development of underdevelopment" (p. 380). The situation, according to Marechera (1980), was made worse by the fact that the social abjection that learners experienced emerged as a manifestation of the overbearing hegemonic relations, narratives, and institutions of late modernity that were brought into Zimbabwe by British imperial colonial rule-and were decided for the learners in their absence. Marechera (1980) exclaimed, "I was hot with resentment and pain. So, this was school. From all sides my head was being jammed with facts. With ideas" (p. 17). The African child suffered deficiencies in accessing knowledge to the same level as those undertaking a European education curriculum (Lugard, 1922; Rodney, 1983) because there was a dual system of education - one for Africans and one for Europeans. Selection of knowledge for African learners was set-and there were no choices regarding what was to be taught; the focus was on surface learning with memorisation and chorusing as part of the learning process (Hoadley, 2018). According to Chung (2006), "African education in the country was a frenzied and irrational race through a jungle of facts that had to be mastered to pass the Rhodesian Junior Certificate" (p. 50). The situation was worsened by the fact that African schools were under the instruction of "native" teachers who focused on the 3Rs (reading, writing, and arithmetic) and imparting elementary religion (Lugard, 1922).

\section{Part 2: The Contingent Path of the Zimbabwean Curriculum Reform Journey}

Curriculum updating is not principally historically predetermined-the curriculum updates in Zimbabwe can be viewed as invaded by contingency, especially given the country's postcolonial education reforms. The social trajectories and realities that surfaced after the colonial period (from the 1980s) in Zimbabwe influenced a shift from curriculum abstraction to a more contextualised curriculum that spoke to local needs and global germaneness or relevance (MoPSE, 2014). During colonial hegemony, cultural technologies of domination were used, but, with the shift in systems of governance, a new social order emerged based on a macro social discourse and ensuring the equality of humankind (Shizha \& Kariwo, 2011).

Pre-independence (1966 and 1979) education reforms included a two-year junior secondary school curriculum (ZJC) and an Education Act that limited access to education for black Zimbabweans (CIET, 1999). The postcolonial Zimbabwean community had to redefine this segregated system of education in a stratified society designed to serve graduates of the colonial education system (Moyana, 1989). The first step taken by the Zimbabwean government was to ensure access to education for all its citizens by building new schools and reopening schools that had been closed during the war for liberation (Gwarinda, 1991). To give traction to the principle of education for all during the years 1980 to 1986, free primary education was introduced to boost enrolment in schools and teacher training was accelerated through programmes such as the Zimbabwe Integrated Teacher Education Course (Maravanyika, 1990).

The early 1990s to mid 2000s marked a shift from reforms that were mainly planning and efficiency reforms to a more focused approach to ensuring educational quality and relevance (CIET, 1999; Ndawi \& Maravanyika, 2011). Talk of revisioning approaches to content, technologies, teaching methodologies, and skills provision became prominent. For example, there was more focus on 
employment-related skills (CIET, 1999), which culminated in the introduction of science, technology, engineering, and mathematics and the Education 5.0 policy (MoPSE, 2014). Another notable shift towards educational quality and relevance was the localisation of all national examinations following the establishment of the Zimbabwe School Examination Council as the country drifted away from the University of Cambridge Local Examinations Syndicate in the United Kingdom.

The blind side of the reforms enacted so far is that they seem to exceed the capacity of the education system to deliver (Ndawi \& Maravanyika, 2011). For instance, the government advocates mass education amidst a critical resource deficit and this appears to be having effects on the educational output of the current curriculum. Thus, it becomes axiomatic to state that Zimbabwe still needs to reform the curriculum so that it becomes anchored in a problem-centred approach to learning in pluralistic contexts and, at the same time, is aligned with the system's capacity to deliver (Ndawi \& Maravanyika, 2011). Waghid et al. (2018) suggested that the educational decolonisation process entails rupturing the dominant ways of meaning making aligned only to a few people, and ensuring that education becomes reflective of the diverse knowledges inherent in the society. It is expected that new reforms will also need to be designed in such a way that learning enables the development of cognitive maturity and opens a hybrid space to recognise contradictions in terms of diversity (Higgs, 1998; Lipman, 2003).

The above propositions demand the strengthening of traditional African institutional structures through reconnecting the learners to their cultural heritage (Zazu, 2012). According to Zazu (2012), precolonial communities in Africa were able to venerate their heritage, a condition that was changed by the advent of colonial rule when the colonisers deliberately caused a dislocation between indigenous people and their own culture. This resulted in the marginalisation of colonised people's knowledge systems and practices in formal education (Shizha \& Kariwo, 2011). This differs substantively from precolonial forms of education, and it is this disjuncture that has motivated a contemporary focus on heritage as a foundation for curriculum reform.

\section{The Contemporary Heritage Response}

Colonial education was premeditated to absorb colonised children into British imperial power (administration) structures by stripping away their indigenous learning configurations (Gwarinda, 1991; Hailey, 1938; Lugard, 1922; Masaka, 2016). It is essential therefore to include in the postcolonial curriculum, heritage practices such as storytelling, axioms, and songs in tandem with indigenous learning lenses that provide start-up capital for curriculum transformation. The next section discusses what heritage is, and its possible implications for education.

\section{What Is To Be Understood as "Heritage"?}

O'Donoghue et al. (2013) postulated heritage as an amalgam of the "tangible and intangible aspects of embodied livelihood practices (some every day and some occasional), is embedded in culture, and is located in diverse contexts and carried across time" (p. 9). The contextualisation of heritage by O'Donoghue et al. (2013) is in accordance with Hountondji's (1996) observation that heritage is never univocal and, hence, can be recognised as plurivocal and contradictory-like all embodied livelihood practices. Furthermore, it has to be understood that heritage has many facets including social, cultural, historical, ethnological, technological, and environmental aspects (Zazu, 2012).

\section{Implications of a Heritage Response to Education}

Given the reform needs highlighted above, it becomes indispensable for postcolonial education systems to embrace heritage education because heritage knowledge and practices form part of 
people's daily lives. As noted by Hountondji (1996), heritage offers people the right traction to define themselves and acquire an identity. Resonating with Hountondji (1996), Magwa (2019) concurred that heritage education has the capacity to develop a sense of ownership, identity, and responsibility in communities and consequently ought to be perceived as fundamental to people's lives. Also, heritage education has the potential to promote students' understanding of themselves and others in relation to place, time, belief, identity, and culture (Hountondji, 1996). An educational programme that values local heritage knowledges and practices is essential in postcolonial Zimbabwe because these aspects were once eclipsed in the "trajectories of colonial and modern expansion" (O`Donoghue et al., 2013, p. 11).

In recent scholarship, there seems to be an emerging reconfiguration of the relationship between heritage knowledge and the communities from which it emerges (Hountondji, 1996; Magwa, 2019; MoPSE, 2014). This reconfiguration has seen some education programmes being reimagined, creating space for the inclusion of heritage education. In Zimbabwe, the quest for a heritage turn has influenced the publication of a book entitled, African Culture and Heritage in Zimbabwe (Magwa, 2019). Arguments proffered in the book buttress the perception that a heritage shift in education is a timely signification for cultural exorcism, which ought to detoxify Africans and, to a larger extent, Zimbabweans and enable them to be more appreciative of their own culture and heritage. Heritagebased education reinforces the idea of exploiting African learning foundations that are aimed at effecting constructive affiliations between educational praxis and theory (rooted in unhu/ubuntu philosophy) and other disciplines and other cross-cutting issues in education (Zazu, 2012). Moreover, educational institutions can also make use of heritage sites (such as Great Zimbabwe, Matopo Hills), which seem to have vibrant educational programmes that could be used as start-up capital in shaping and informing schools' heritage education programmes.

\section{Centring of Unhu/Ubuntu in Contemporary Curriculum Discourse}

CIET (1999) and MoPSE (2014) emphasised the need to underpin the Zimbabwean education system with unhu/ubuntu philosophy as an antithesis to coloniality, and demonstrated the authority of this philosophy in strengthening and deepening contemporary Zimbabwean education. Talk, as reasoned by Fairclough (1995) in reference to discourse, is never neutral because it is grounded in language and text that is socially situated and as such has embodied meanings (Pinar et al., 1995). In Zimbabwe, the conversation is based on critical insights from diverse scholars that the postcolonial Zimbabwean education system was informed by cultural technologies of dominance that seem to have their orientation in Kant's notion of universal reason ${ }^{5}$ as contradistinguished from unhu/ubuntu philosophy, which is communalistic in outlook (Hountondji, 1996). These cultural technologies of dominance have curtailed opportunities in Zimbabwean "civilization" (Gwarinda, 1991; Moyana, 1989).

Abdi (2005) resonated with this, theorising that the colonial education system had deleterious power in that it unsettled "the values of pre-settler and pre-colonial notions of learning [that] were essential in reflecting the social and cultural needs and expectations of the community" (p. 29). The cultural imperialism described by Abdi (2005) was perceived by Shizha and Kariwo (2011) to be what kept Zimbabwean citizenry in perpetuity in a position of inferiority to Europeans and influenced their internalisation of the racial stereotypes of the coloniser. Evidently, the discourse foregrounds a shift from what Giroux (1988) observed as a macro socio-political level of understanding curriculum. At this level, Giroux (1988) reasoned, the aim behind reorienting curriculum towards incorporating local heritage knowledge is to link curriculum content to the learners' reality.

\footnotetext{
${ }^{5}$ According to Marshall (2004), Kant advanced the notion of universal reasoning by arguing that improvement of humanity was to be achieved through the critical use of reason in its universal applications.
} 
It follows that the postcolonial community found it worthwhile to deconstruct the values entrenched by the coloniality (which sought to immortalise colonial hegemony) through centring postcolonial learning on the indigenous philosophy of unhu/ubuntu (CIET, 1999; MoPSE, 2014). In line with this viewpoint, Shizha and Kariwo (2011) echoed the need for decolonisation, reasoning that "as Africans, we need to invent ways of rewriting or changing those dominant narratives and deconstruct 'White' superiority and the misrepresentation of indigenous people and their cultures" (2011, p. 14).

Given the viewpoint above, and the supporting literature from CIET (1999) and MoPSE (2014), it appears that anchoring the curriculum on an indigenous philosophy could open the channel through which Zimbabwe can demythologise (Mbembe, 2015) the colonial history of curriculum, and usher in innovative perspectives to teaching and learning. Additionally, underpinning the education system with the unhu/ubuntu philosophy is important in order to "explicate, understand and criticize" (Hirst, 2010, p. 37) preliminary principles of the Zimbabwean education system. Here, unhu/ubuntu can become the benchmark for approaching education from a situated local context and can give to the education system what Lotz-Sisitka et al. (2017) described as a paradigm of learning as connection, which bestows on education a social function that Dewey (1944) anticipated in his ideas on democracy and education.

The significance of unhu/ubuntu in contemporary Zimbabwe was first highlighted by Samkange and Samkange (1980) who intimated that the philosophy "inspires, permeates and radiates . . regulates our well-planned social and political organisations" (p. 34). Though Samkange and Samkange (1980) did not explicitly advocate for unhu/ubuntu to be the anchor of the Zimbabwean education system, they described how, in precolonial indigenous societies, "education of the individual was not only by members of the immediate or extended family; it was also by any member of the community" (p. 77). Thus, they positioned communalism, a key aspect of unhu/ubuntu philosophy, as the basis of African education.

Samkange and Samkange (1980) therefore can be seen as the precursors of centring unhu/ubuntu in curriculum discourse in Zimbabwe. Makuvaza (1996) took this further, advocating that unhu/ubuntu become the philosophical foundation of modern Zimbabwean education. Several others joined the conversation (CIET, 1999; MoPSE, 2014; Ramose, 1999), with Ramose (1999) reasoning that:

[Unhu/]Ubuntu is the root of African philosophy. The being of an African in the universe is inseparably anchored upon [unhu/]ubuntu. Similarly, the African tree of knowledge stems from [unhu/]ubuntu with which it is connected indivisibly. [Unhu/]Ubuntu then is the wellspring flowing with African ontology and epistemology. (p. 49)

It follows that education for the African child should take root from the philosophy that connects and speaks to their lifeworld, and this philosophy is the philosophy of unhu/ubuntu-important and wellknown amongst mainstream citizenry. As noted by Prinsloo (2013), referring to South Africa but applicable to southern Africa more generally, "it promises to respond to the fragmentation" of the sense of southern African place (p. 2).

\section{Post-Colonial Discourse Analysis of Unhu/Ubuntu Discourse in the Curriculum}

According to Fairclough and Wodak (1997), discourse analysis is a theoretical and methodological approach that helps us study "how power relations, and ideological standpoints, are exercised and negotiated in discourse" (p. 272). To understand what underlies arguments in support of centring the curriculum on unhu/ubuntu, I have used postcolonial discourse analysis. According to Sawyer (2012), 
postcolonial theories adopt the concept of discourse to examine how modern thought, which is understood as "the complex of signs and practices that organize social existence and social reproduction within colonial relationships" (Ashcroft et al., 2000, p. 42), resists decolonization. (p. 39)

In this study, the focus was more on the macro elements and politics of discourse than the micro linguistic type of discourse analysis. The macro elements in postcolonial discourse analysis are useful in revealing how language, power, and ideology are often hidden from people in written text, the spoken word, or in other optical signs (Fairclough \& Wodak, 1997).

In light of the above, intertextual analysis was employed to show how texts build on other texts to make meaning (Sawyer, 2012). Intertextuality and metaphors are useful in unearthing the ideological positions and cultural claims of a text or discussion in education. The current school curriculum made extensive use of other texts, especially the CIET (1999), to explore unhu/ubuntu and for reimagining the curriculum underpinned by an indigenous philosophy. Given that the updated school curriculum is said to be anchored on unhu/ubuntu, this analysis hopes to uncover some of the pitfalls at the level of unhu/ubuntu interpretation that may become barriers to the implementation of the curriculum. Venter (2004) cautioned that unhu/ubuntu seems to carry a flawed interpretation that results in its meaning becoming ambiguous or unclear, an observation that seems useful because it helps to unearth the postcolonial paradox of superficial interpretation of unhu/ubuntu that, ironically, can become a doxa. Moreover, it mirrors the limitations and successes that have thus far been encountered in educational reforms aimed at decolonising the curriculum.

Evident in CIET (1999) and MoPSE (2014), is the identification of unhu/ubuntu with communalism, humanism, and holism or the interpretation of unhu/ubuntu as one of the principles that guide educational provision in Zimbabwe. The following quotations from the updated curriculum framework The Curriculum Framework for Primary and Secondary Education 2015-2022 (MoPSE, 2014) provide a good starting point for exploring how unhu/ubuntu is construed in the curriculum.

"Respect (ubuntu/unhu/vumunhu)" is the fifth principle underpinning the curriculum (p. 5 and p. 16).

In addition, we see "self-respect and respect for others (ubuntu/unhu/vumunhu)" on page 6 and "the processes of building consciousness and patriotism is possible through drawing on ubuntu/ unhu/vumunhu" on page 19.

On the list of learners' exit profiles, ubuntu/unhu/vumunhu is listed among values such as discipline and honesty ( $p .17)$.

The updated curriculum framework mentions unhu/ubuntu under the heading: "Philosophy underpinning the national curriculum" as follows: "Unhu/Ubuntu/Vumunhu epitomises universal human inter-dependence, solidarity, humanness and a sense of community common in African societies" (p. 13).

From the foregoing, there is no doubt that MoPSE (2014) built its understanding of unhu/ubuntu through making reference to the CIET (1999) report which included the following recommendations and interpretations on unhu/ubuntu:

"The concept of unhu/ubuntu should be introduced, developed and be the torchlight of our moral education" (p. 69). 
"Unhu/ubuntu then is a concept that denotes a good human being, a well behaved and morally upright person, characterized by qualities such as responsibility, honesty, justice, trustworthiness, hardworking, integrity, a cooperative spirit, solidarity, hospitality, devotion to family and the welfare of the community" (p. 62).

"The school should promote holistic education and expound the unhu/ubuntu philosophy" (p. 79).

It is evident from the two documents that emphasis is on the development of a morally upright person inclined to a communal approach to social and personal problems. While communalism, humanism, and holism can be considered aspects of unhu/ubuntu philosophy, Hapanyengwi and Shizha (2012) cautioned against mistaking the part for the whole. The principle of holism is rooted in the African belief that reality is to be perceived as a whole and not fragmented (Wiredu, 2008), while that of humanism emanates from a consideration of human needs, dignity, and welfare (Gyekye, 1987). According to Hountondji (1996), there is a dialectical relationship between a philosophy and its principles. However, this does not mean that the essence of unhu/ubuntu philosophy can be adequately captured by these principles (Chitumba, 2013; Hapanyengwi \& Shizha, 2012). Thus, in advocating unhu/ubuntu as an educational philosophy centred on holism, CIET (1999) and MoPSE (2014) may have masked ethnocentric norms and values. Here, unhu/ubuntu appears to be a postcolonial façade popularised to mask ideas from non-indigenous sensitivities.

Furthermore, in positioning unhu/ubuntu as an epitome of human solidarity, CIET (1999) and MoPSE (2014) seem to be committing the fallacy of ad populum in which there is no deep conceptual analysis behind a theory or belief but simply reliance on popularity of that belief or theory (Lau, 2011, p. 179). Considering the Zimbabwean cultural, religious, and knowledge practice disparities that can be equated with those more generally in southern Africa, it could be observed that unhu/ubuntu is not the great integrator of all human understanding into a unified view of humans (Hountondji, 1996). One may therefore surmise that ideological persuasion may have been used to conceal the idea of cultural pluralism in depth. Such a conclusion arises from the fact that ideologies are also regarded to be a form of social cognition used to capture the way that people share broader ideas about the way the world works (Machin \& Mayr, 2012). However, unhu/ubuntu philosophy cannot be equated with an ideology if we consider Althusser's definition of ideology as a process that obscures the fact that dominant forces in society are operating in a systematic manner to oppress people (Machin \& Mayr, 2012). This is contrary to philosophy that aims to analyse sociopolitical issues in depth and uncover the hidden reality (Hountondji, 1996; Waghid et al., 2018). Moreover, ideologies have the potential of creating a dualistic hybrid co-engagement characterised by the internalisation of oppression by indigenous people, which also translates into the oppressed assimilating habits and mannerisms of the oppressor (Freire, 1970). The resulting effect of this is creation of the problem of superficial interpretation of concepts in education.

\section{An Emerging Problem of Superficial Interpretation of Unhu/Ubuntu Philosophy}

The second part of my analysis focused on the discourse of ubuntu/unhu, and found a contradiction in the superficial interpretation of this philosophy in the postcolonial Zimbabwe curriculum. In so doing, unhu/ubuntu has plunged into a state of philosophical fragility due to the superficial ascriptions in both CIET (1999) and MoPSE (2014), Zimbabwe's national school curriculum review documents. The problem of superficiality seems to have misled other thinkers to believe unhu/ubuntu could be applied as a blanket that covers all in solving educational problems in the country (CIET, 1999; MoPSE, 2014)particularly those related to decolonising the curriculum and centring issues of indigenous knowledge. While superficiality abounds in philosophical discourse with philosophers such as Nietzsche 
foregrounding it by promoting the absenting of depth/profundity in favour of multiple surfaces (Castle, 2007), Marxist sociologists tend to disregard superficiality on the grounds that it appears to be a façade aimed at concealing the possibility of exploring other critical alternatives (Hardt \& Weeks, 2000). The superficial positionality of unhu/ubuntu philosophy in the CIET (1999) and MoPSE (2014) curriculum review documents has a negative pedagogical influence in the Zimbabwean education system because it focuses mainly on the ontological being. This focus on the ontological is paradoxically an emergent problem piloted by the locating of African philosophy largely in prehistorical epochs (Higgs, 2012), and it presents the need to define a philosophy of the future that could be achieved through offering a deepened understanding of unhu/ubuntu as a philosophy for curriculum transformation.

\section{Discussion}

The question that now arises is how the postcolonial African focus on curriculum transformation can avoid the dialectics of opposites Eze (2008), especially those that emerge between a need to maintain an African identity (ontological being status) and the need for deep epistemic engagement in pedagogy that calls for inclusion into the curriculum of a diverse conception of knowledge heritages from diverse geo-epistemic locations. In response, I argue that a deeper engagement with the unhu/ubuntu philosophy and associated heritage discourse is essential if we are to meet the intended aspirations of decoloniality in contemporary times.

Curriculum transformation should be grounded on unhu/ubuntu, and it should consider being responsive to the African human condition (Waghid et al., 2018). This entails that people exposed to unhu/ubuntu as a philosophy of curriculum transformation should be capable of thinking through a variety of life's problems and facing all the facts impartially. Basically, unhu/ubuntu in Zimbabwe should take educational graduates through a process of reflecting on and criticising their deeply held conceptions and beliefs (Chitumba, 2013)-especially those beliefs that were propagated in them through coloniality.

Furthermore, as argued by Hountondji (1996) and Wiredu (1998), any philosophy of curriculum transformation must aim to be the main informant in a critical examination of the conceptual framework upon which the thought of a culture is erected. Critical examination here entails that unhu/ubuntu pedagogical philosophy is positioned as a critique of the colonial education conceptual inheritance, and assessed for its practicability through a nuanced understanding of the inheritance's procedural terminology and paradigms associated with it (Hountondji, 1996; Wiredu, 1998). In practice, unhu/ubuntu should foster development of a third space in which colonially designed historical narratives are challenged and reshaped, paving the way for new alternatives in educational thinking (Bhabha, 1990). In this regard, unhu/ubuntu takes the form of a decolonial philosophy that sought to disentangle people who were once colonised from the continuities of coloniality (NdlovuGatsheni, 2013). Thus, where indigenous people were regarded as primitive with nothing to offer in terms of knowledge construction, their heritage knowledge should be seen as part of the broader ecology of knowledge commons (Hailey, 1938). In so doing, an Afrophilia learning lens can become a space for collaboration and resistance in which indigenous peoples have room to negotiate their identities - not based on identity politics but on epistemic depth. The unique aspect of an Afrophilia learning lens, an offshoot of unhu/ubuntu philosophy within third space narrative, is that the third space, as argued by Bhabha (1990), is not locked in the past but is a channel that has potential to let other positions emerge.

To accomplish the above propositions, unhu/ubuntu has to be the foundation upon which rationality and reasonability are enacted because this will give it depth and the analytic tools that are a necessary condition for any philosophy of education (Hountondji, 1996). Wiredu (1998) has argued for a move beyond surface-level interpretations to deeper levels of understanding that question existing 
assumptions. Henceforth, in the context of unhu/ubuntu as decolonial philosophy of education, analytic tools need to help the philosophy chart deliberations on the question of values and the purpose of education.

Emerging insights on unhu/ubuntu as a decolonial paradigm that surface from a reading of Hountonji (1996) and Waghid et al. (2018) are suggestive of the notion of divesting African philosophical thinking broadly, and unhu/ubuntu in particular, of all undue influences emanating from the colonial history of curriculum. Hence, the proposition that unhu/ubuntu be considered as the missing humanistic approach in education theory and praxis. This will allow for an integration of the subject content with the feelings, emotions, experiences, and lives of the learners (Wiredu, 1998). The vantage point in taking a humanist approach is that instead of letting learning be abstracted, the learners become fully engaged in learning processes that draw on content and methods from their heritage knowledge.

From the above discussion, we note that the aim of schooling under the guidance of the unhu/ubuntu philosophy of curriculum transformation should be twofold. It should aim firstly, to extend the learner's knowledge of the data of human experience and secondly, as argued by Higgs (1998) and Lipman (2003), to perfect the child's acquired knowledge by teaching the child what he or she needs to know. Unhu/ubuntu should not be superficial. Hountondji (1996) believed that African philosophy must be an episteme rather than a doxa. Considering this point of view, I am of the opinion that schooling, starting from early childhood education, should take an epistemological and ontological shift in which it aims to arrive at a rational and systematic comprehension of reality. According to Lipman (2003), inquiry in schooling processes should aim to investigate the nature of knowing itself.

\section{Need for Curriculum Praxis and Pedagogical Development}

In practice, this has implications for reframing curriculum in ways that can realise epistemic depth in pedagogy as a means of avoiding the limitations of doxa. The unhu/ubuntu heritage focus should open a hybrid space through which Zimbabwe could avoid a decolonisation process that tends to represent teleological curriculum reforms that are linear and unidimensional (Magwa, 2019). A shift from unidimensional curriculum reforms has potential to help Zimbabweans move beyond self-location and create space for critical reflection that translates into a deeper analysis of the present reality-from which the Zimbabwean identity would evolve as a continuation rather than a fixed identity (Hountondji, 1996). This, in turn, has implications for pedagogy, the role of the teacher, and the sociocultural foundations of educational theory and practice.

The likely implications invoke a need for an intervention such as a "philosophy for children" (Lipman, 2003, p. 43), which promotes in learners the habits of critical reflexive thinking. Introducing philosophy for children seems useful in that it could help learners and teachers navigate pathways that lead to the avoidance of knowledge transmission and the presenting of sanitised and neatly packaged information that overlooks diversity and, unwittingly, reinforces a particular worldview (Hountondji, 1996; Lipman, 2003). The intervention has traction in learning contexts that emphasise a curriculum grounded in local heritage because here, learning is perceived as an outgrowth of the learners-hence, encouraging learners to be able to think out problems for themselves.

\section{Conclusion}

This paper provides an opportunity for historical and historical social critique, from which future studies can provide an understanding of the advanced theories and methods that translate into later educational change. The broader discussion of the paper is that Zimbabwe's education system should not blinker itself by focusing only on the ontological, which leads to superficiality, but should also acknowledge diversity in reason. Reasoning in diversity based on unhu/ubuntu values creates space 
for ethical critical thinking and creativity that takes into account local heritage knowledge in educational reform, an experience that is both educational and social. With this in mind, unhu/ubuntu as a decolonial philosophy should focus on promoting deeper epistemological participation in education, which I have identified in the article as a necessary link to bring about change in education.

\section{References}

Abdi, A. A. (2005). African philosophies of education: Counter-colonial criticisms. In A. A. Abdi \& A. Cleghorn (Eds.), Issues in African education: Sociological perspectives (pp. 25-41). Palgrave.

Abdi, A. A. (2009). Oral societies and colonial experiences: Sub-Saharan Africa and the de facto power of the written word. In D. Kapoor (Ed.), Education, decolonization and development (pp. 42-59). Sense.

Abdi, A. A (Ed.). (2012). Decolonising philosophies of education. Sense.

Achebe, C. (2000). Home and exile. Oxford University Press.

Ashcroft, B., Griffiths, G., \& Tiffin, H. (2007). Post-colonial studies: The key concepts. Routledge.

Bhabha, H. K. (1990). The third space: Interview with Homi Bhabha. In J. Rutherford (Ed.), Identity, community and difference (pp. 207-221). Lawrence \& Wishart.

Castle, G. (2007). The Blackwell guide to literary theory. Blackwell.

Chitumba, W. (2013). University education for personhood through ubuntu philosophy. International Journal of Asian Social Science, 3(5), 1268-1276.

Chung, F. (2006). Re-living the second chimurenga: Memories from the liberation struggle in Zimbabwe. NORDIC Africa institute.

Dewey, J. (1944). Democracy and education: An introduction to philosophy of education. The Free Press.

Fairclough, N. (1995). Critical discourse analysis. Addison Wesley.

Fairclough, N., \& Wodak, R. (1997). Critical discourse analysis. In T. van Dijk (Ed.), Discourse as social interaction (pp. 258-285). SAGE.

Freire, P. (1970). Pedagogy of the oppressed. Herder \& Herder.

Giroux, H. G. (1988). Literacy and the pedagogy of voice and political empowerment. Educational Theory, 38(1), 61-75.

Gwarinda, J. (1991). Socialism and education. College Press. http://wiser.wits. ac.za/system/files/Achille.pdf

Gyekye, K. (1987). An essay on African philosophical thought: The Akan conceptual scheme. Cambridge University Press.

Hailey, L. (1938). An African survey: A study of problems arising in Africa south of the Sahara. Oxford University Press.

Hapanyengwi, O., \& Shizha, E. (2012). Unhu/ubuntu and education for reconciliation in Zimbabwe. Journal of Contemporary Issues in Education, 7(2), 16-27.

Hardt, M., \& Weeks, K. (2000). The Jameson reader. Blackwell.

Higgs, P. (1998). Philosophy of education in South Africa: A re-vision. Studies in Philosophy of Education, 17(1), 1-16.

Higgs, P. (2012). African philosophy and the decolonisation of education in Africa: Some critical reflections. Educational Philosophy and Theory, 44(2), 37-55. 
Hirst, P. H. (2010). Knowledge and the curriculum: A collection of philosophical papers. Routledge \& Kegan Paul.

Hoadley, A. (2018). Pedagogy in poverty: Lessons from 20 years of curriculum reform in South Africa. Routledge.

Hountondji, P. (1996). African philosophy: Myth and reality. Indiana University Press.

Kallaway, P. (1984). Apartheid and education: The education of black South Africans. Ravan Press.

Lau, J. Y. F. (2011). An introduction to critical thinking and creativity: Think more, think better. John Wiley \& Sons.

Lipman, M. (2003). Thinking in education. Cambridge University Press.

Lotz-Sisitka, H., Shumba, O., Lupele, J., \& Wilmot, D. (2017). Schooling for sustainable development in Africa. Springer.

Lugard, F. D. (1922). The dual mandate in British tropical Africa. William Blackwood \& Sons.

Machin, D., \& Mayr, A. (2012). How to do critical discourse analysis: A multimodal introduction. SAGE.

Magwa, W. (2019). African culture and heritage in Zimbabwe (Vol. 1). Mambo Press.

Makuvaza, N. (1996). Missionary education in Africa in perspective: Against the theory of benevolence. Zimbabwe Bulletin of Teacher Education, 4(4), 59-74.

Maravanyika, O. (1990). Implementing educational policy in Zimbawe: World Bank discussion paper No 91, Africa Technical Department Series. World Bank.

Marechera, D. (1980). Black sunlight. Heinemann.

Marshall, J. (2004). Living systemic thinking: Exploring quality in first person research. Action Research, 2(3), 309-329.

Masaka, D. (2016). The impact ofWestern colonial education on Zimbabwe's traditional and postcolonial educational system(s) [Unpublished doctoral thesis]. University of South Africa.

Mbembe, A. (2015). Decolonising knowledge and the question of the archive. http://wiser.wits. ac.za/system/files/Achille.pdf

Mgqwashu, E. (2016, March 16). Education can't be for "the public good" if universities ignore rural life. The Conversation. https://theconversation.com/education-cant-be-for-the-public-good-ifuniversities-ignore-rural-life- 56214

Moyana, T. F. (1989). Education, liberation and creative act. Zimbabwe Publishing House.

Ndawi,O., \& Maravanyika, O. (2011). Curriculum and its building blocks concepts and processes. Mambo Press.

Ndlovu-Gatsheni, S. (2013). Why decoloniality in the 21st century? The Thinker, 48, 10-15.

O'Donoghue, R., Shava, S., \& Zazu, C. (2013). African heritage knowledge in the context of social innovation. United Nations University Institute for Advanced Studies.

Pinar, W., Renolds, W., Slattary, P., \& Taubman, P. (1995). Understanding curriculum: An introduction to the study of historical and contemporary curriculum discourses. Peter Lang.

Presidential Commission of Inquiry into Education and Training (CIET). (1999). Report of the presidential commission of inquiry into education and training. Government Printers.

Prinsloo, A. V. (2013). Prolegomena to ubuntu and any other future South African philosophy [Unpublished master's thesis]. Rhodes University, South Africa.

Ramose, M. B. (1999). African philosophy through ubuntu. Mond Books. 
Rodney, W. (1983). How Europe underdeveloped Africa. Bogle-L'Ouverture.

Said, E. (1985). Orientalism reconsidered. Cultural Critique, 1, 89-107.

Samkange, S. J., \& Samkange, T. M. (1980). Hunhuism or ubuntuism: A Zimbabwe indigenous political philosophy. Graham Publishing.

Sawyer, J. B. (2012). A postcolonial discourse analysis of the Tenth Grade science curriculum guide. [Unpublished master's thesis]. University of Saskatchewan.

Sever, M. (2012). A critical look at the theories of sociology of education. International Journal of Human Sciences, 9(1), 650-671.

Shava, S. (2008). Indigenous knowledges: A genealogy of representations and applications in developing contexts of environmental education and development in Southern Africa [Unpublished doctoral thesis]. Rhodes University, South Africa.

Shizha, E., \& Kariwo, M. T. (2011). Education and development in Zimbabwe: A social, political and economic analysis. Sense.

Siyakwazi, P. D. F., \& Siyakwazi, B. J. (2013). The dawn of progressive teaching and learning in teacher education. Booklove.

Subrt, J. (2017). The Perspective of historical sociology: The individual as homo-sociologicus through society and history. Emerald.

Terreblanche, S. (2014). Western empires, Christianity, and the inequalities between the West and the rest 1500-2010. Penguin Books.

Tranfield, D., Denyer, D., \& Smart, P. (2003). Towards a methodology for developing evidenceinformed management knowledge by means of systematic review. British Journal of Management, 14, 207-222.

Venter, E. (2004). The notion of ubuntu and communalism. Studies in Philosophy and Education, 23, 149-160.

Wa Thiong'o, N. (1986). Decolonising the mind: The politics of language in African literature. EAEP.

Waghid, Y., Waghid, F., \& Waghid, Z. (2018). Rupturing African philosophy on teaching and learning: Ubuntu justice and education. Palgrave Macmillan.

Wiredu, K. (1998). The moral foundations of an African culture. In P.H. Coetzee \& A.P. J. Roux (Eds.), The African philosophy reader. Routledge.

Wiredu, K. (2008). Social philosophy in postcolonial Africa: Some preliminaries concerning communalism and communitarianism. South African Journal of Philosophy, 27(4), 332-339.

Zazu, C. (2012). Representation and use of indigenous heritage constructs: Implications for the quality and relevance of heritage education in post colonial southern Africa [Unpublished doctoral thesis]. Rhodes University, South Africa.

Zimbabwe Ministry of Primary and Secondary Education [MoPSE]. (2014). Curriculum framework for primary and secondary education 2015-2022. http://mopse.co.zw/sites/default/files/public/downloads/Zim Curriculum Framework.pdf 